\title{
Formation Conditions of Copper Porphyry Mineralization in the Kadica-Bukovik Ore District, Eastern Macedonia
}

\author{
A. V. Volkov ${ }^{a}$, G. Tasev ${ }^{b}$, V. Yu. Prokof'ev ${ }^{a}$, T. Serafimovski ${ }^{b}$, \\ Corresponding Member of the RAS I. N. Tomson ${ }^{a}$, \\ and Corresponding Member of the RAS A. A. Sidorov ${ }^{a}$
}

Received December 12, 2007

DOI: $10.1134 / \mathrm{S} 1028334 \mathrm{X} 08050127$

Macedonia is located in the Serbian-Macedonian sector of the Eurasian Tethys metallogenic belt (Fig. 1). Mineralization related to Cenozoic activation in this area is expressed in the formation of a volcanoplutonic complex in the dispersed spreading setting [1].

Previous joint works with Macedonian geologists made it possible to establish that the present-day tectonic structure of Macedonia reflects dislocations closely related to Cenozoic magmatism and productive mineralization [2].

The Kadica-Bukovik ore district is located in the easternmost Surdulica-Osogovo-Pasos metallogenic zone characterized by the wide development of leadzinc mineralization (Fig. 1). The zone incorporates systems of sheeted bodies and discordant dikes of quartz latites with an absolute age within 24-12 Ma. Recent discovery of the gold-bearing porphyry copper mineralization in the eastern Kadica ore district is inconsistent with its metallogenic specialization and previous metallogenic model of this belt [2]. To study this phenomenon, we carried out complex studies, which involved structural-geomorphological analysis of ore district [4], on the one hand, and thermobarogeochemical study of ore formation conditions, on the other hand.

The Kadica ore field. Copper mineralization near the town of Pehchevo was recently discovered and preliminarily estimated. The Kadica deposit is localized at the contact between Neogene quartz latites and volcanosedimentary rocks of the Vlasina Group. The host

\footnotetext{
${ }^{a}$ Institute of Geology of Ore Deposits, Petrography, Mineralogy, and Geochemistry, Russian Academy of Sciences, Staromonetnyi per. 35, Moscow, 119017 Russia e-mail: alexandr@igem.ru

${ }^{b}$ Faculty of Mining and Geology, Kiril and Methodie University of Skopje, Goce Delcev 89, 92000 Shtip, Macedonia
}

rocks represent hydrothermally altered quartz latites and partially schists (rocks subjected to alunitization, sericitization, and silicification). Copper mineralization in quartz latites is developed as stockworks and dissemination. Major ore minerals are represented by pyrite, chalcopyrite, magnetite, and hematite. Enargite, pyrargyrite, tetrahedrite, galena, sphalerite, and pyrrhotite are less common. Quartz is the main gangue mineral. In terms of morphology, link with porphyry intrusion, and

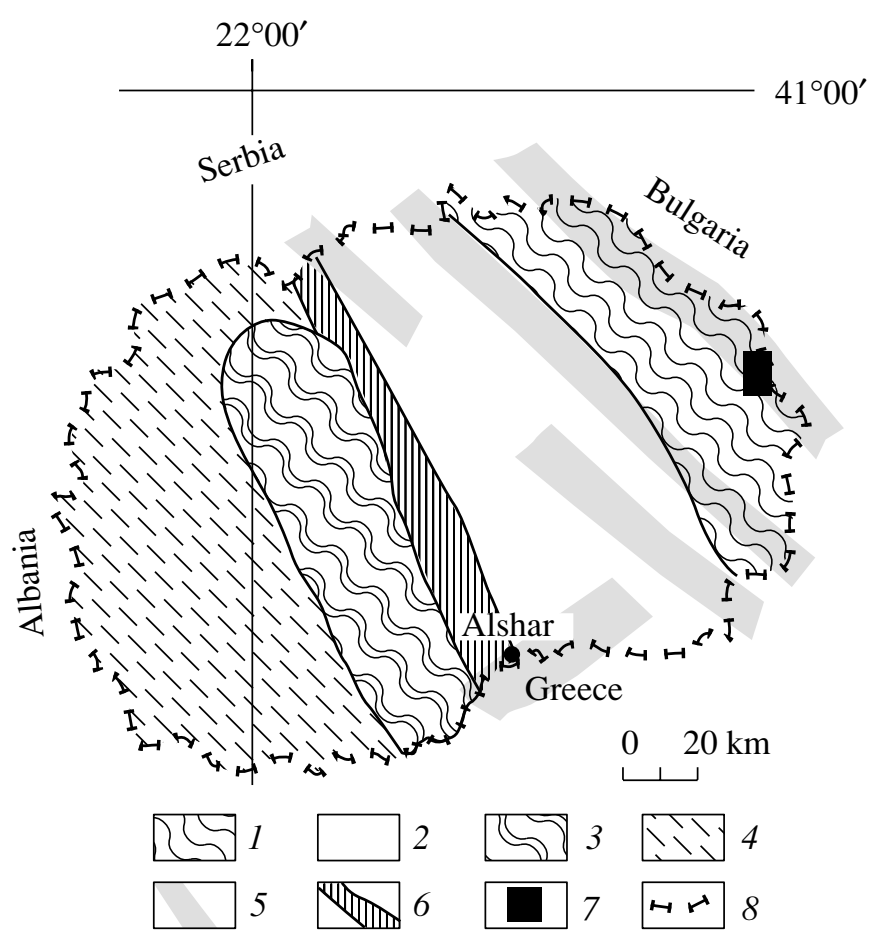

Fig. 1. Tectonic scheme of Macedonia. (1) Serbian-Macedonian massif; (2) Vardar rift graben; (3) Pelagonian massif, (4) Western Macedonian area; (5) Cenozoic metallogenic zone and fault systems; (6) Vardar metallogenic zone; (7) Kadovica-Bukovik ore district; (8) border of the Macedonian Republic. 


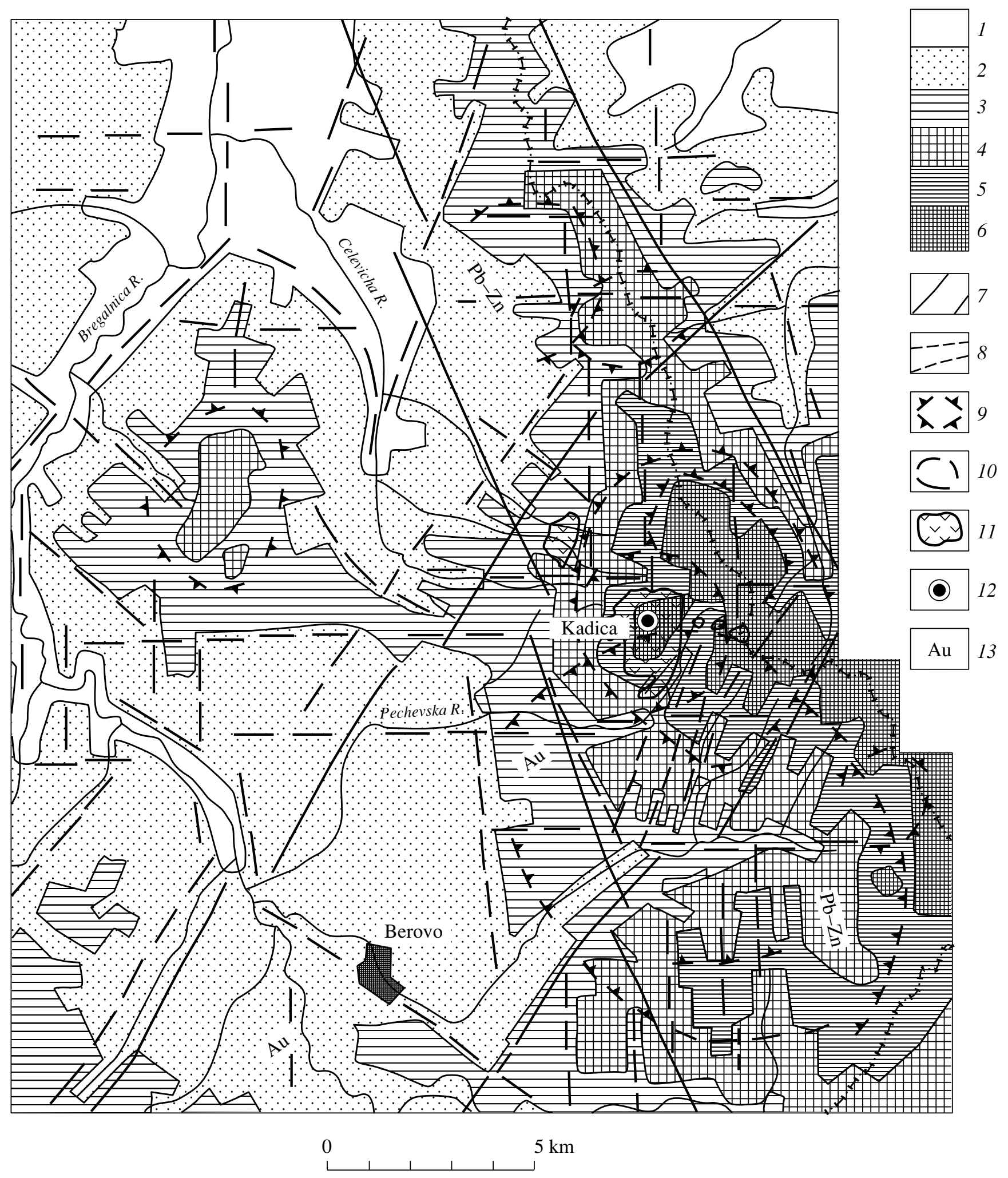

Fig. 2. Morphostructural scheme of the Kadica-Bukovik area. (1-6) Hypsometric levels (m): (1) below 800, (2) 800-1000, (3) 1000-1200, (4) 1200-1500, (5) 1500-1700, (6) above 1700; (7) metallogenic zones; (8-10) structures deciphered from topographic maps and satellite images; (8) linear dislocations, (9) boundaries of ring structures, (10) ring dislocations; (11) outcrops of Pliocene volcanic rocks, (12) Kadica deposit, (13) specialization of metallogenic zones. 
composition, the deposit is classed with the copper porphyry type. Some of the aforementioned minerals and wallrock alterations are also typical of sulfidized epithermal deposits [5].

Results of structural-geomorphological analysis. The Kadica-Bukovik ore district is located at the upper reaches of the Bregalnica, Pechevska, and Celevich rivers. The waterways form two systems: a centrifugal system in the upper reaches of the Bregalnica River and a centripetal system in the Kadica plain. The northern part of the area represents moderate mountains (altitude up to $1700-1900 \mathrm{~m}$ ). The relatively lower, southern part (up to $1000-1300 \mathrm{~m}$ ) is crosscut by a wide sublatitudinal valley and numerous small waterflows emptying 1 into the main riverbed. From the north and east, the rel2 atively lowered part of the area is surrounded by an arcuate ridge with an altitude ranging from 1600 to $1700 \mathrm{~m}$. Radial-centripetal and radial-centrifugal patterns of waterflows in both the uplifted and lowered parts make it possible to distinguish the intersecting oval southern $(11 \pm 8 \mathrm{~km})$ and northern $(7.5 \pm 6 \mathrm{~km})$ structures (Fig. 2). Altitude marks, erosion reworking, and alluvium accumulation, which are typical of the morphology of valleys and slopes, indicate a descending (ascending) evolution of the southern (northern) oval. Intersection of distinguished ovals is complicated by a ring structure $3.5 \mathrm{~km}$ across. The central part of this structure coincides with the autonomous Bukovik Uplift elevated up to $1700 \mathrm{~m}$. The most uplifted part of the Bukovik structure contains large massif of Pliocene volcanic rocks. The uplift is bounded by a ring depres2 sion belt, which is emphasized by arcuate valleys of the upper reaches of the Celevich, Pechevska, and Rakovec rivers (Fig. 2). In the east, the structure is rimmed by an 2 arcuate uplift 1700-1900 $\mathrm{m}$ high.

It was found that the distinguished group of ring structures is localized at the intersection of two metallogenic zones-the base metal Surdulica-OsogovoPasos zone and the auriferous Kuzuf-Arid zone. The latter zone extends from the Alshar gold deposit [3] and contains Pliocene mineralization along the entire zone (Figs. 1, 2). The Kuzuf-Arid metallogenic zone occupies a specific position at the southern end of Macedonia (Fig. 1). In addition to the Alshar deposit, this zone contains several $\mathrm{Sb}-\mathrm{As}-\mathrm{Au}$ occurrences, porphyry copper deposits, and manifestations of native sulfur. The mineralization is distinctly related to the Pliocene volcanoplutonic complex, which is developed along the main regional fault zone between the Pelagonian crystalline block in the west and the Vardar zone in the east. The rocks of the complex are represented by different andesites and quartz latites. Volcanic and intrusive activity lasted from 7 to $1.8 \mathrm{Ma}$ [1].

The intersection of the two aforementioned zones has a complex structure. For example, the Bukovik ring structure is located exactly at the junction of orthogonal fault systems revealed by linear tectonic elements of modern relief. Meridional dislocations are traced as
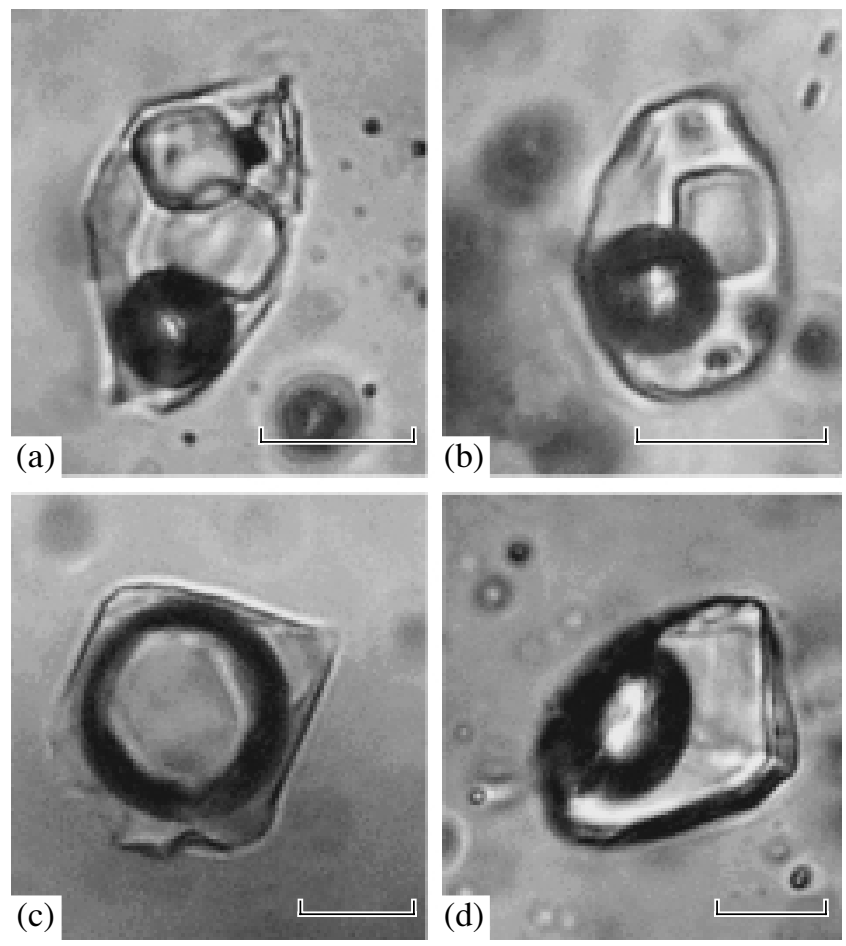

Fig. 3. Types of fluid inclusions in quartz from ores of the Kadica deposit: (a, b) brine inclusions (type I); (c) gas inclusion (type II), (d) two-phase inclusion of undersaturated solutions (type III). Scale bar is $10 \mu \mathrm{m}$.

highly fissured belts, which are deciphered on satellite images and expressed as accumulations of small linear elements of relief in the topographic map. Numerous latitudinal systems are emphasized by tectonic scarps, bends of large rivers, and modern grabenlike depressions.

Ore formation conditions at the Kadica deposit were studied by thermobarogeochemistry [6-9]. Study of numerous transparent polished plates with an Olimpus BX51 optical microscope equipped with high-resolution objectives made it possible to investigate primary fluid inclusions $(8-16 \mu \mathrm{m}$ in size) in quartz from veinlets in quartz latites. Quartz samples were taken from stockwork, which was exposed along a road over more than $100 \mathrm{~m}$, and from a borehole core.

The studied fluid inclusions can be subdivided into three main types (Fig. 3): (I) inclusions of chloride brines containing a gas bubble, aqueous solution, one or several isotropic crystals, and, occasionally, opaque ore mineral; (II) mainly gas inclusions containing gas with a thin rim of aqueous solution (occasionally with cubic isotropic crystal); and (III) two-phase gas-liquid inclusions of undersaturated solutions. Fluid inclusions evenly distributed over individual quartz grains and regarded as primary inclusions were selected for thermo- and cryometric studies. 
Results of thermo- and cryometric studies of individual primary fluid inclusions in quartz from ore veinlets of the Kadica and Alshar deposits (Macedonia)

\begin{tabular}{|c|c|c|c|c|c|c|c|c|}
\hline \multirow{2}{*}{$\begin{array}{c}\text { Inclusions } \\
\text { no. }\end{array}$} & \multirow{2}{*}{$\begin{array}{l}\text { Inclusion } \\
\text { type }\end{array}$} & \multirow{2}{*}{$n$} & $T_{\text {hom }}$ & $T_{\text {eut }}$ & $T_{\text {ice melt }}$ & \multirow{2}{*}{$\begin{array}{l}C_{\text {salts }}, \text { wt } \% \\
\mathrm{NaCl} \text { equiv. }\end{array}$} & \multirow{2}{*}{$\underset{\mathrm{g} / \mathrm{cm}^{3}}{d,}$} & \multirow{2}{*}{$\begin{array}{c}\text { Pressure, } \\
\text { bar }\end{array}$} \\
\hline & & & \multicolumn{3}{|c|}{${ }^{\circ} \mathrm{C}$} & & & \\
\hline \multicolumn{9}{|c|}{$\mathrm{Kadica}$} \\
\hline 1 & III & 3 & 627 & -60 & -27.4 & 24.3 & 0.58 & - \\
\hline 2 & III & 4 & 476 & -42 & -19.7 & 21.2 & 0.72 & - \\
\hline 3 & I & 3 & 333 & -55 & $(311)$ & 38.9 & 1.06 & - \\
\hline 4 & I & 3 & 334 & -55 & (299) & 38.2 & 1.06 & - \\
\hline 5 & I & 2 & 346 & -55 & (289) & 37.4 & 1.04 & - \\
\hline 6 & I & 4 & 331 & -54 & (283) & 36.9 & 1.05 & - \\
\hline 7 & I & 5 & 310 & -55 & (383) & 45.6 & 1.16 & 1620 \\
\hline 8 & I & 3 & 326 & -54 & (294) & 37.7 & 1.06 & - \\
\hline 9 & I & 2 & 340 & -49 & (259) & 35.2 & 1.02 & - \\
\hline 10 & III & 2 & 439 & -48 & -24.5 & 23.2 & 0.79 & - \\
\hline 11 & II & 2 & $463 @$ & -38 & -7.0 & 10.5 & - & 480 \\
\hline 12 & III & 3 & 360 & -25 & -1.9 & 3.2 & 0.60 & - \\
\hline 13 & III & 3 & 378 & -35 & 6.9 & 10.4 & 0.70 & - \\
\hline 14 & III & 3 & 432 & -36 & -10.1 & 14.0 & 0.66 & - \\
\hline 15 & II & 5 & $438 @$ & -25 & -3.9 & 6.3 & - & 390 \\
\hline 16 & I & 4 & 337 & -55 & (211) & 32.4 & 1.00 & - \\
\hline 17 & III & 2 & 526 & -55 & -19.9 & 22.3 & 0.65 & - \\
\hline 18 & II & 3 & $497 @$ & -54 & -12.4 & 16.3 & - & 630 \\
\hline 19 & I & 2 & 328 & -55 & $(255)$ & 35.0 & 1.03 & - \\
\hline 20 & I & 3 & 501 & -55 & (317) & 39.5 & 0.90 & - \\
\hline \multicolumn{9}{|c|}{ Alshar } \\
\hline $\mathrm{S}-2$ & & 3 & 238 & -21 & -2.1 & 3.6 & 0.85 & - \\
\hline & & 4 & 219 & -22 & -1.6 & 2.7 & 0.87 & - \\
\hline
\end{tabular}

The results of thermo- and cryometric studies of 374 individual fluid inclusions in quartz and calcite (table, Fig. 4) showed that hydrothermal solutions consist mainly of chlorides of $\mathrm{Na}$ and $\mathrm{Ca}$ (occasionally, $\mathrm{Mg}$ ). This conclusion follows from chloride eutectics of solutions within temperature intervals from -42 to $-25^{\circ} \mathrm{C}$ and from -60 to $-48^{\circ} \mathrm{C}$, as well as from the presence of daughter halite, which was identified by the similarity of the refractive index of the daughter cubic crystal to quartz and its transition into hydrohalite upon freezing of the inclusion solutions (reverse transition to halite occurred at $0.0-0.5^{\circ} \mathrm{C}$ ). A complete homogenization of brine inclusions is attained at $501-326^{\circ} \mathrm{C}$, while their salinity is $45.6-32.4 \mathrm{wt} \% \mathrm{NaCl}$ equiv. Pressure estimated from inclusions of saturated brines is $1620 \mathrm{bar}$ at $383^{\circ} \mathrm{C}$. The fluid density varies from 1.16 to $0.90 \mathrm{~g} / \mathrm{cm}^{3}$.

Gas-dominated fluid inclusions homogenize into gas at $497-438^{\circ} \mathrm{C}$ and contain fluid with a salinity of $16.3-6.3$ wt $\% \mathrm{NaCl}$ equiv. These inclusions define a pressure within 630-390 bar.
Two-phase gas-liquid fluid inclusions of diluted solutions homogenize into liquid at $627-360^{\circ} \mathrm{C}$, and the eutectic temperature varies from -60 to $-25^{\circ} \mathrm{C}$, indicating their chloride composition and the presence of $\mathrm{Ca}, \mathrm{Na}$, and $\mathrm{Mg}$ ions. The salinity of these inclusions is $24.3-3.2 \mathrm{wt} \% \mathrm{NaCl}$ equiv., and the fluid density varies from 0.58 to $0.72 \mathrm{~g} / \mathrm{cm}^{3}$.

The inclusions from the Carlin-type Alshar deposit, which is also located in the Kozuf-Arid metallogenic zone, were studied for comparison [1]. The table shows that primary fluid inclusions in quartz from the Alshar deposit homogenize into the liquid phase at $238-219^{\circ} \mathrm{C}$ and contain an aqueous solution with salinity 3.6$2.7 \mathrm{wt} \% \mathrm{NaCl}$ equiv. Fluid inclusions are dominated by sodium chloride (eutectic temperature from -22 to $-21^{\circ} \mathrm{C}$ ). The fluid density is $0.88-0.87 \mathrm{~g} / \mathrm{cm}^{3}$.

The thermobarogeochemistry of fluid inclusions in quartz and calcite from veinlets of ore stockwork showed that the hydrothermal solution was dominated by chlorides of $\mathrm{Na}$ and $\mathrm{Ca}$ (occasionally, $\mathrm{Mg}$ ). Brine inclusions homogenize completely at $501-326^{\circ} \mathrm{C}$ and 


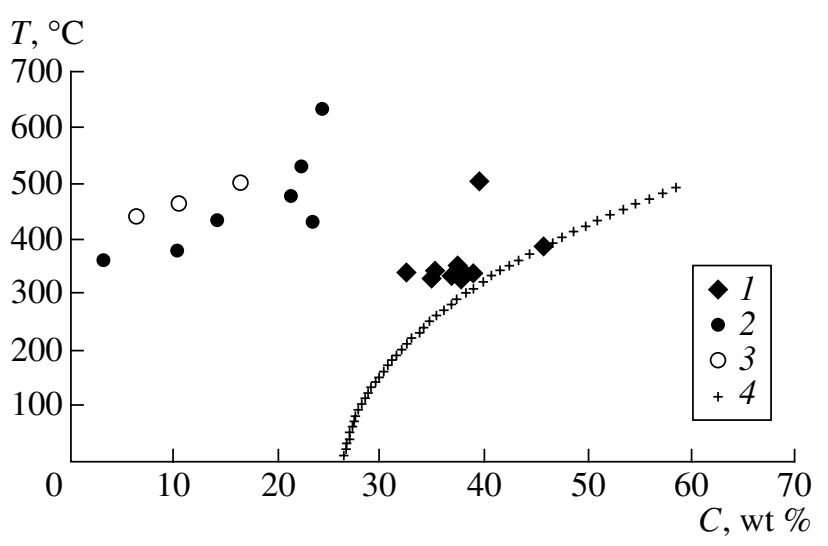

Fig. 4. Temperature vs. salinity diagram for different types of ore-forming fluid in the Kadica deposit. (1) Brine; (2) gas, (3) undersaturated solution; (4) saturation curve of $\mathrm{H}_{2} \mathrm{O}-\mathrm{NaCl}$ system.

have a salinity of 45.6-32.4 wt \% NaCl equiv. Pressure is 1620 bar for inclusions of saturated brines and 630 390 bar for gas inclusions.

Thus, structural-geomorphological analysis showed that the Kadica ore field occupies a specific structural position within eastern Macedonia. It is confined to the central part of the ring structure situated at the junction of two large orthogonal fault zones and the corresponding metallogenic zones of different ages (the base metal Surdulica-Osogovo-Pasos and the auriferous KuzufArid). Based on morphostructural studies, this structure represents a center of long-term endogenic activity lasting from the Neogene to the Pleistocene. The thermobarogeochemical data obtained are typical of the formation conditions of porphyry copper deposits. They are most contrasting as compared to fluid inclusion data on quartz from jasperoids of the Carlin-type Alshar gold deposit. The Kadica ore field is promising for the discovery of gold mineralization.

\section{ACKNOWLEDGMENTS}

This work was supported by the Division of Earth Sciences of the Russian Academy of Sciences (program no. 2 "Fundamental Problems of Geology, Formation Conditions, and Principles of the Prediction of Traditional and New Types of Large Deposits of Strategic Raw Minerals").

\section{REFERENCES}

1. S. Jankovic, Neues Jahrb. Mineral. Abh., 166, 25 (1993).

2. I. N. Tomson, T. Serafimovski, and N. T. Kochneva, Geol. Ore. Dep. 40, 175 (1998) [Geol. Rudn. Mestorozhd. 40, 195 (1998)].

3. T. J. Percival and A. Radtke, Can. Mineral. 32, 649 (1994).

4. A. Volkov, H. Thomson, A. Sidorov, and N. Kochneva, in Proceedings of the 5th European Congress on Regional Geoscientific Cartography and Information Systems, Barcelona, Spain, 2006 (Inst. Geol. Catalon., Barcelona, 2006), pp. 238-240.

5. A. V. Volkov, N. E. Savva, A. A. Sidorov, et al., Geol. Ore Dep. 48, 448 (2006) [Geol. Rudn. Mestorozhd. 48, 512 (2006)].

6. R. J. Bodnar and M. O. Vityk, Fluid Inclusions in Minerals: Methods and Applications, Ed. by B. de Vivo and M. L. Frezzotti (Pontignano, Sienna, 1994), pp. 117-130.

7. V. Yu. Prokof'ev and I. N. Kigai, Practical Thermobarogeochemistry. Modern Methods of Studying Fluid Inclusions in Minerals: A Handbook for Postgraduate and Senior Students of the Geological Prospecting Faculty of the Moscow Geological Prospecting Academy (IGEM, Moscow, 1999) [in Russian]).

8. V. A. Kalyuzhnyi, Principles of the Science of MineralForming Solutions (Naukova Dumka, Kiev, 1982) [in Russian].

9. P. Brown, Am. Mineral. 74, 1390 (1989).

SPELL: 1. riverbed, 2. arcuate 